\title{
The unconventional hydrocarbon resources of Greece
}

\author{
Ananias TSIRAMBIDES , * $^{1}$ \\ 1 School of Geology, Aristotle University of Thessaloniki, Department of Mineralogy-Petrology-Economic Geology, Egnatias \\ 131, 54124 Thessaloniki, Greece
}

Tsirambides, A., 2015. The unconventional hydrocarbon resources of Greece. Geological Quarterly, 59 (3): 479-490, doi: 10.7306/gq.1219

\begin{abstract}
Intensive exploration of probable conventional hydrocarbon reservoirs in Greece is taking place, through the interpretation of seismic profiles and of abundant surface geological data. The unconventional hydrocarbon potential of the country is unknown, as detailed investigations are lacking. The most important rock formations which may contain shale gas are found in the land and offshore basins of northeastern, north-central, and western Greece. A re-evaluation of the data from all boreholes is needed, on the basis of new information, with the aim of identifying possible reserves of unconventional hydrocarbons retained in highly compacted fine-grained strata. Methane hydrates have been detected in the submarine Anaximander Mountains, east of Rhodes Island. They cover an area of about $46 \mathrm{~km}^{2}$ and the volume of methane is estimated at 2.6-6.4 trillion $\mathrm{m}^{3}$. The low content of the Greek lignites in gaseous hydrocarbons and the widespread tectonics in the Hellenic Peninsula are the main factors which prevented large gas accumulations in its 14 main coal deposits. However, additional research is needed to evaluate the coal-bed gas potential of the country.
\end{abstract}

Key words: shale gas, gas hydrates, coal bed gas, Greece.

\section{INTRODUCTION}

Greece, in relation to many other countries of similar size, possesses very abundant reserves of energy mineral raw materials, such as lignite. However, the future of lignite in Greece is uncertain. Further exploration is needed, new and improved mining methods must be applied, beneficiation methods must be implemented, and underground mining must be initiated (Koukouzas et al., 1997; Tsirambides and Filippidis, 2012).

The probable and proven reserves of almost all the hydrocarbon resources of Greece are unknown, as detailed investigations (e.g., boreholes, measurements, analyses, etc.) are lacking. The USGS (U.S. Geological Survey), the IODP (Integrated Ocean Drilling Project), the Geophysical Institute of France (FIGR), and the Norwegian seismic survey companies TGS-Nor and PGS have made in the last 40 years numerous explorations and drilled many boreholes in the international waters of the eastern Mediterranean (and hence within the Greek Exclusive Economic Zone-EEZ). According to their published reports, the oil reserves of Greece may be in the order of tens of billions of barrels, and its natural gas reserves of tens of trillions of $\mathrm{m}^{3}$ (Tsirambides and Filippidis, 2012).

The total value of the fossil fuel reserves of Greece is $€$ 1,417 billion, of which $€ 268$ billion belong to the lignites which were exploited for decades to produce only electricity. The esti-

\section{*E-mail: ananias@geo.auth.gr}

Received: November 4, 2014; accepted: February 16, 2015; first published online: March 26, 2015 mated oil reserves are 10 billion barrels, with a current gross value of $€ 719$ billion, and the natural gas reserves are 3.5 trillion $\mathrm{m}^{3}$ with a current gross value of $€ 430$ billion (Tsirambides and Filippidis, 2012).

Nowadays, reserves of conventional oil and gas, which can be produced cheaply, are limited. This is why many of the major oil companies invest in what we commonly call "unconventional resources". Large reserves of such hydrocarbons, retained in layered and highly-compacted deposits, exist in many countries. The main types are: tight gas, coal-bed methane, shale gas, shale oil, heavy oil/tar sands, and methane (gas) hydrates.

European shale gas resources are estimated at 16 trillion $\mathrm{m}^{3}$, compared to 20 trillion $\mathrm{m}^{3}$ for the US. However, it will take more time for exploration to find out how much can be extracted at a reasonable cost. Europe could start producing gas from shale in the next 3-4 years.

Shale gas deposits are possible in all areas where shales or other fine-grained and highly-compacted strata exist below the groundwater level, with significant extent and organic matter content $>1 \%$. During their geological history, they were formed under conditions corresponding to the gas window (generally to depths over 5,000 m).

The sedimentation of dark, organic-rich deposits in basins is mainly controlled by climatic changes and changes in the carbonate-compensation depth. In addition, basin morphology, input of terrestrial organic material, and local volcanic activity are other significant factors controlling the deposition of these sediments. Jurassic to Lower Cretaceous black, organic-rich pelitic deposits are considered targets for unconventional hydrocarbon exploration in the Outer Carpathians and adjacent part of the Alps. These anoxic or poorly-oxygenated deposits (average total organic carbon [TOC] is $2.5 \mathrm{wt}$. \%) were laid down in indi- 
vidual basins over a period of 30 to $50 \mathrm{Myr}$, and their thickness reached hundreds of metres (Ślączka et al., 2014).

The most important Jurassic to Neogene rock formations which may contain shale gas are found in the land and offshore basins of northeastern (e.g., Evros Delta-Orestias, Lemnos Island, Kavala-Prinos-Nestos Delta, Epanomi-Thermaikos Gulf), north-central (e.g., Mesohellenic), and western Greece (e.g., Diapondia islands, Preveza, Zakynthos Island, Peloponnesus basins). Gas hydrates are found in the submarine Anaximander Mountains, east of Rhodes Island. They cover an area of about $46 \mathrm{~km}^{2}$ and the volume of methane is 2.6-6.4 trillion $\mathrm{m}^{3}$. With approximately 43 active open-cast coalmines, Greece holds the 2nd position in the EU and 11th worldwide in the production of coal (only lignite). The extensive tectonics across the whole Hellenic Peninsula and the low content in gaseous hydrocarbons of the Greek lignites are the main factors which prevented large gas accumulations in the coal deposits. Additional research to evaluate the coal-bed gas potential is needed (Papanicolaou et al., 2005; Lykousis et al., 2009; Tsirambides and Filippidis, 2012).

\section{GEOTECTONIC SETTING OF GREECE}

The Hellenic Peninsula consists of three orogenic belts:

1 - the Cimmerian internal belt, created in pre-Late Jurassic time as a result of the collision of northwards drifted Cimmerian continental fragments with Eurasia;

2 - the Alpine orogenic belt, created in the Cretaceous-Paleogene after the Neo-Tethyan subduction beneath the Cimmerian-Eurasian plate and the collision of the Apulian microplate with this plate;

3 - the Mesogean orogenic belt along the External Hellenic Arc, which resulted from the underplating of the Mesogean-African plate beneath the Alpine-Cimmerian-Eurasian plate in the Miocene-Pliocene.

Paleogene Alpine collisions formed the nappe pile of the Hellenic orogen. Late orogenic extension followed the lithosphere thickening and caused the collapse and crustal thinning with exhumation of the lower crustal units as metamorphic core complexes in Crete, southern Peloponnesus, and the Cyclades. In addition, a series of tectonic windows in continental Greece (e.g., the windows of Olympus, Ossa, Rizomata and Krania) were formed, consisting of Mesozoic and Paleogene neritic carbonates (Mountrakis, 2006).

Northern Greece is dominated by the Alpine orogenic evolution, the major events of which involve (Papanikolaou, 1980):

1. The pre-Alpine zones (e.g., Rhodope and Serbomacedonian) of Paleozoic, which comprise the internal part of the Hellenic Arc and therefore are called the Internal Hellenides. They consist of high-grade metamorphic rocks (e.g., migmatites, gneisses, amphibolites and marbles);

2. The palaeo-Alpine orogenic characteristics are represented by large segments of the Tethyan oceanic crust of Late Jurassic-Early Cretaceous age (mainly ophiolites and pelagic deposits), which were overthrusted on to pre-Alpine and Alpine rocks;

3. The Alpine zones (e.g., Ionian, Gavrovo, Pindos, SubPelagonian, Pelagonian, Axios, Circum Rhodope) which comprise the external part of the Hellenic Arc and therefore are called the External Hellenides. They are composed of Mesozoic and Cenozoic rock units (e.g., flysch, neritic and pelagic limestones, dolomites and their low metamorphic derivatives, such as crystalline limestones, schists, phyllites and quart- zites). The Alpine orogeny started in the Late Eocene, culminated during the Oligocene and Miocene, and continues today;

4. The post-Alpine formations, which consist of sedimentary and volcanic rocks of Miocene, Pliocene and Quaternary age, rest unconformably on Alpine rocks. The extended molasse deposits, occurring across the Hellenides, are considered to be related to Alpine back-arc basins, rather than to post-Alpine structures. These basins are shown in Figure 1 (IGMEM, 2012).

Northern Greece is a complex of grabens, basins, and horsts, arranged in a primary NW-SE trend. Intermountainous high-level grabens (e.g., Ptolemais-Florina) or low-level grabens (e.g., Mygdonia) and large coastal basins and plains (e.g., Axios-Thermaikos, Serres-Strymon) were filled with Paleogene to Quaternary sedimentary deposits (Psilovikos et al., 1987). Sediment thicknesses vary depending on palaeotopography, local erosion events, and local tectonics.

Western Greece is dominated by the External Hellenides fold-and-thrust belt, namely the pre-Apulian (Paxi), Ionian and Gavrovo zones. From the Triassic to Late Cretaceous, western Greece was part of the Apulian continental block on the southern passive margin of the Tethys Ocean. Little is known about the pre-Mesozoic evolution of western Greece. Mesozoic rocks are rarely exposed at the surface. The oldest known lithology comprises Triassic evaporites, which are heavily tectonized and dominated by anhydrite, gypsum, and halite in some boreholes. The thickness of the evaporites, the lithology underneath them, and the tectonic movements in western Greece are crucial factors in the hydrocarbon exploration within this region (Marnelis et al., 2007; Karakitsios, 2013).

The Ionian Zone is bounded by the pre-Apulian Zone in the west, and by the Gavrovo Zone in the east. In the Early Miocene, major compressional events affected the previous stratigraphy and structural style, due to the westwards merging of the Ionian Zone. In the Pliocene and Quaternary, continued regional compression resulted in uplift of the Ionian Zone. Detailed examination of many boreholes which penetrated the Ionian Zone show that the thickness of its Mesozoic rock formations varies from 1.2 to $3.8 \mathrm{~km}$ in the north, from 1.1 to 3.5 $\mathrm{km}$ in the centre, and from 1.5 to $3.9 \mathrm{~km}$ in the south. However, data from seismic sections show that the thicknesses of these Mesozoic formations may reach 8 km (Zelilidis et al., 2003; Mavromatidis, 2009).

\section{CONVENTIONAL HYDROCARBONS}

Today, no sufficient data exists to substantiate the presence of proven oil reserves in Greece, except that of Thassos, the daily output of which has been limited to 2,000 barrels. Hypothetically, however, we can accept the presence of oil and natural gas, since all the neighbouring countries of Greece in the eastern Mediterranean host substantial oil and gas fields, and have exploited these resources for decades. The last confirmation of this hypothesis is the agreement in 2010 on the delimitation of the EEZ between Israel and Cyprus.

Encouraging evidence for the existence of oil are in Katakolo Peloponnesus, in the huge basin of the Ionian Sea and in the two basins SW (Syrti Basin) and SE (Herodotus Basin) of Crete. Also, in all the lonian islands, on the western mainland coast, in the basin of Grevena, Gulf of Thermaikos, Chalkidiki, in Stavros and Maronia Rhodope, Tavri Evros, in the islets of Babouras Thassos and Zourafa Samothrace, and in the islands of Lemnos, Lesvos, Ikaria, Skopelos, and SE Cyclades (Tsirambides and Filippidis, 2012). 


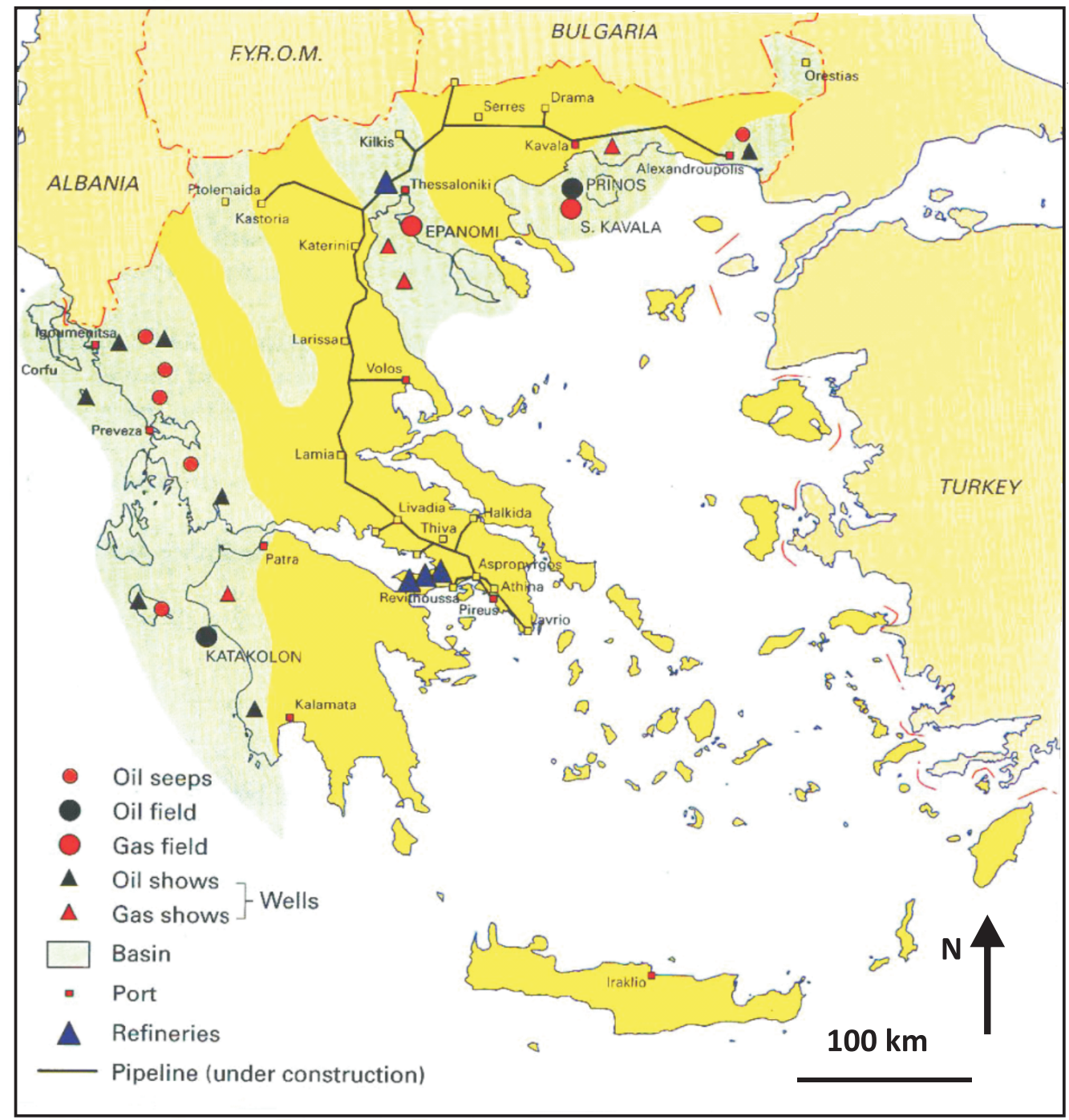

Fig. 1. Sedimentary basins of Greece (in light green colour)

under exploration; in yellow colour areas with insignificant hydrocarbon potential (IGMEM, 2012)

Except for the exploitation of gas from Thassos, which is almost depleted, other large reserves may be found in the lonian Sea and in the two basins SW (Syrti Basin) and SE (Herodotus Basin) of Crete. Smaller gas deposits have been located in Babouras Thassos and Epanomi Thessaloniki. The former Energy Director of the Cyprus Republic, S. Kasinis (pers. comm., 2012), estimates that $70 \%$ of the world gas reserves exist in the huge basin of the Mediterranean Sea and the surrounding countries. At least $5 \%$ of it belongs to Greece (Tsirambides and Filippidis, 2012).

Accretionary prisms throughout the world (e.g., Barbados, Makran, Irrawaddy-Andaman, West Timor Trough, etc.) are indicative of giant hydrocarbon deposits. A large number of accretionary prisms are encountered within the Mediterranean Ridge (MR), the principal structure in the eastern Mediterranean Sea. Hence, nowadays, the existence of large to giant hydrocarbon deposits is the subject of intense exploratory research within this ridge (Foscolos et al., 2012). The MR stretches from the Calabrian Rise in the west to the Florence Rise in the east, a distance of about $1,500 \mathrm{~km}$. The ridge width ranges from 150 to $300 \mathrm{~km}$, and it has an arcuate southward convex shape, almost parallel to the Hellenic Arc. The average water depth on the MR is about 2.1-2.2 km, varying between $1,200 \mathrm{~m}$ and more than $3,000 \mathrm{~m}$. The ridge rises $1-2 \mathrm{~km}$ above the sea-floor, but because of its large width, the general slope rarely exceeds $20^{\circ}$ (Le Pichon et al., 1982).

Underneath Crete, in the region where the African plate is subducting, there are many active mudflow volcanoes, pockmarks, and pipenecks, which have been emitting methane for thousands of years. As a result, a thorough investigation could reveal giant oil fields. Geochemical analysis of emitted methane bubbles from active mud-flow volcanoes indicates that their origin is thermogenic. This implies that pyrolysis (thermal cracking) of hydrocarbons takes place at depth where temperatures are 160 to $180^{\circ} \mathrm{C}$. Based on a geothermal gradient of $33^{\circ} \mathrm{C} / 1,000 \mathrm{~m}$, pyrolysis should take place at the lower layers of the sea-bottom deposits with a thickness of at least 5,000 m. Hence, working petroleum systems southern of Crete may be encountered at such depths (Foscolos et al., 2012).

In the Ionian and Paxi zones, a significant presence of methane gases has been located, mainly of biogenic origin. These gases are hosted in reservoirs with coarse-grained Plio- 


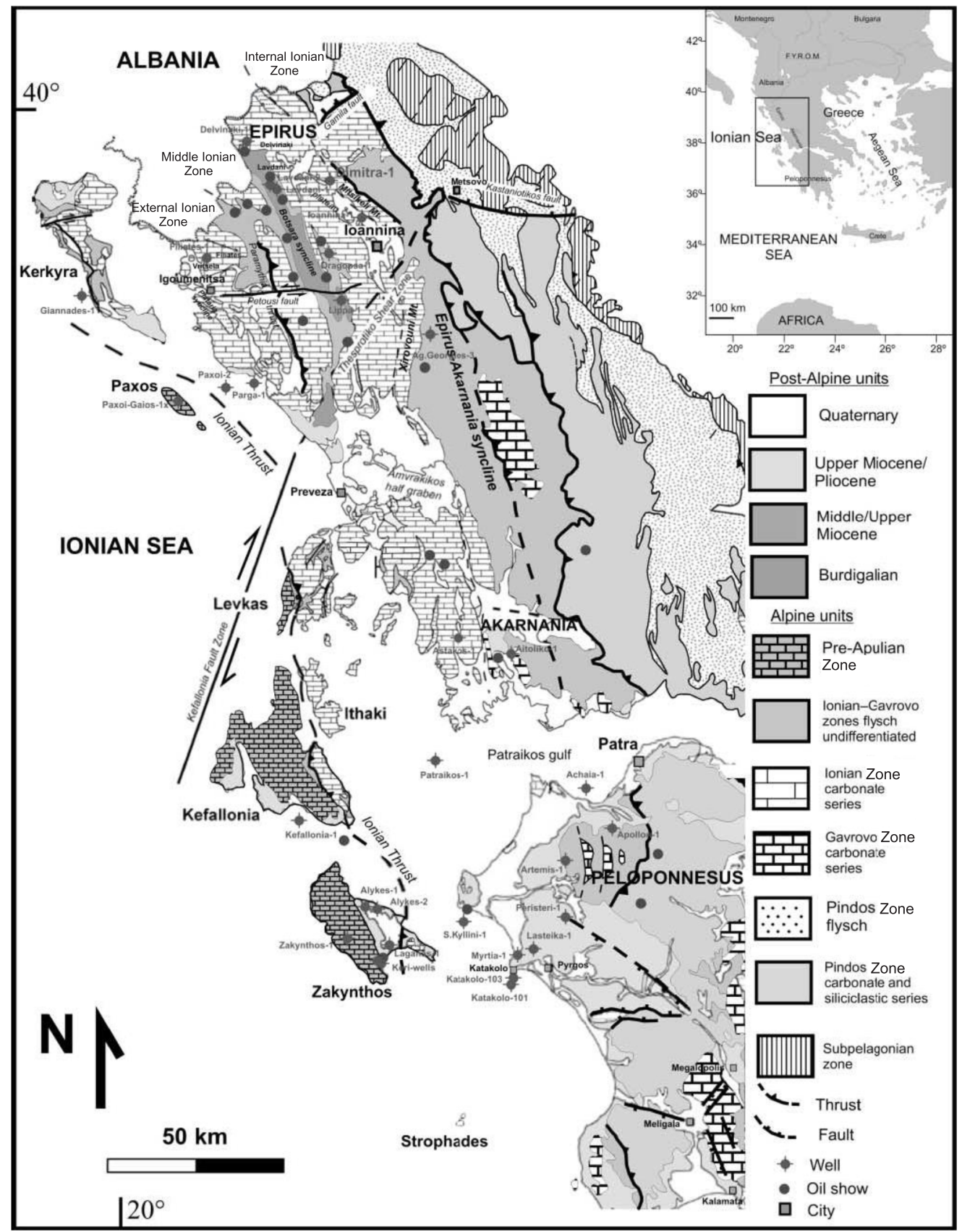

Fig. 2. Geological sketch map of western Greece, indicating the Alpine zones with their flysch, the post-Alpine deposits, the boreholes, and the principal oil show locations (Karakitsios, 2013)

cene deposits, with porosity of $22-30 \%$. Other catagenic gases are trapped in reservoirs with flysch or carbonate deposits of Eocene and Mesozoic age (Karakitsios, 2013).

A great number of oil shows on surface are known in western Greece, mainly in the Ionian Zone, but also in the preApulian and Gavrovo zones (Fig. 2). Most of the wells drilled in the area have also identified oil shows. Their presence indicates that oil generation and migration have certainly taken place. Furthermore, by their study, the petroleum systems of western Greece can be constrained. Most surface oil shows are biodegraded (Rigakis et al., 2007).

Last year's extensive exploration, especially offshore from Greece, gave encouraging results. The important hydrocarbon systems of Greece are being investigated in detail through the interpretation of seismic profiles and the abundant surface geological data. In December 2014, consortium companies were granted permission by the Greek parliament for hydrocarbon exploration and exploitation in the areas (YPEKA, 2012b): a - gulf of Patraikos (west) (offshore) with reserves of about 200 million barrels;

$\mathrm{b}$ - Katakolo (offshore) with reserves of about 7 million barrels;

c - loannina (onshore) with reserves of about 80 million barrels.

Seismic research data acquisition of non-exclusive use within the marine areas of the Ionian Sea and south of Crete Island were held by the Norwegian Petroleum Geo-Services (PGS; YPEKA, 2011a, b, 2012a). The research was completed 
in April 2013 and the data processing in December 2013. The Notice from the Government of the Greek Republic for granting and using licenses for the prospection, exploration, and production of hydrocarbons was published in the official journal of the EU in November 2014. The second round of concessions of the twenty marine blocks ends in July 2015 (YPEKA, 2014).

\section{UNCONVENTIONAL HYDROCARBONS}

\section{SHALE GAS}

In Greece, promising oil and gas shale reservoirs exist, which must be added to its hydrocarbon potential. However, the possible traps need verification, predominantly by modern seismic methods.

The lonian and pre-Apulian (Paxi) zones of western Greece contain fine-grained source rocks, found within the gas window, from which shale gas may be produced. The shale layers are intercalated within the subsurface evaporites of the Ionian (Tri- assic) and pre-Apulian (Triassic-Early Jurassic) zones, respectively. The Gavrovo and Ionian zones of western Greece contain significant underground immature - or close to the early maturation stage - source rocks, with black shales rich in organic content (Fig. 3). Some of them have sufficient thicknesses and are located below $1,500 \mathrm{~m}$ depth. They can be artificially converted by in situ heating (pyrolysis), generally to $350-500^{\circ} \mathrm{C}$ so that most of the oil can be generated from the contained kerogen. The promising areas where shale gases and oils exist need systematic and detailed seismic investigation (Kafousia et al., 2011; Karakitsios, 2013).

In western Greece, siliceous facies are widely associated with organic carbon-rich deposits. The Pre-Apulian Zone consists mostly of Triassic to Miocene mixed neritic-pelagic carbonates. Hydrocarbon source rocks include pelagic deposits rich in marine organic material, although terrigenous organic matter is also found in the clastic deposits. The lonian Zone consists of sedimentary rocks, ranging from Triassic evaporites to Jurassic-Upper Eocene carbonates and minor cherts and shales, overlain by Oligocene flysch. Organic-rich intervals occur within Triassic evaporites and Jurassic-Cretaceous pelagic

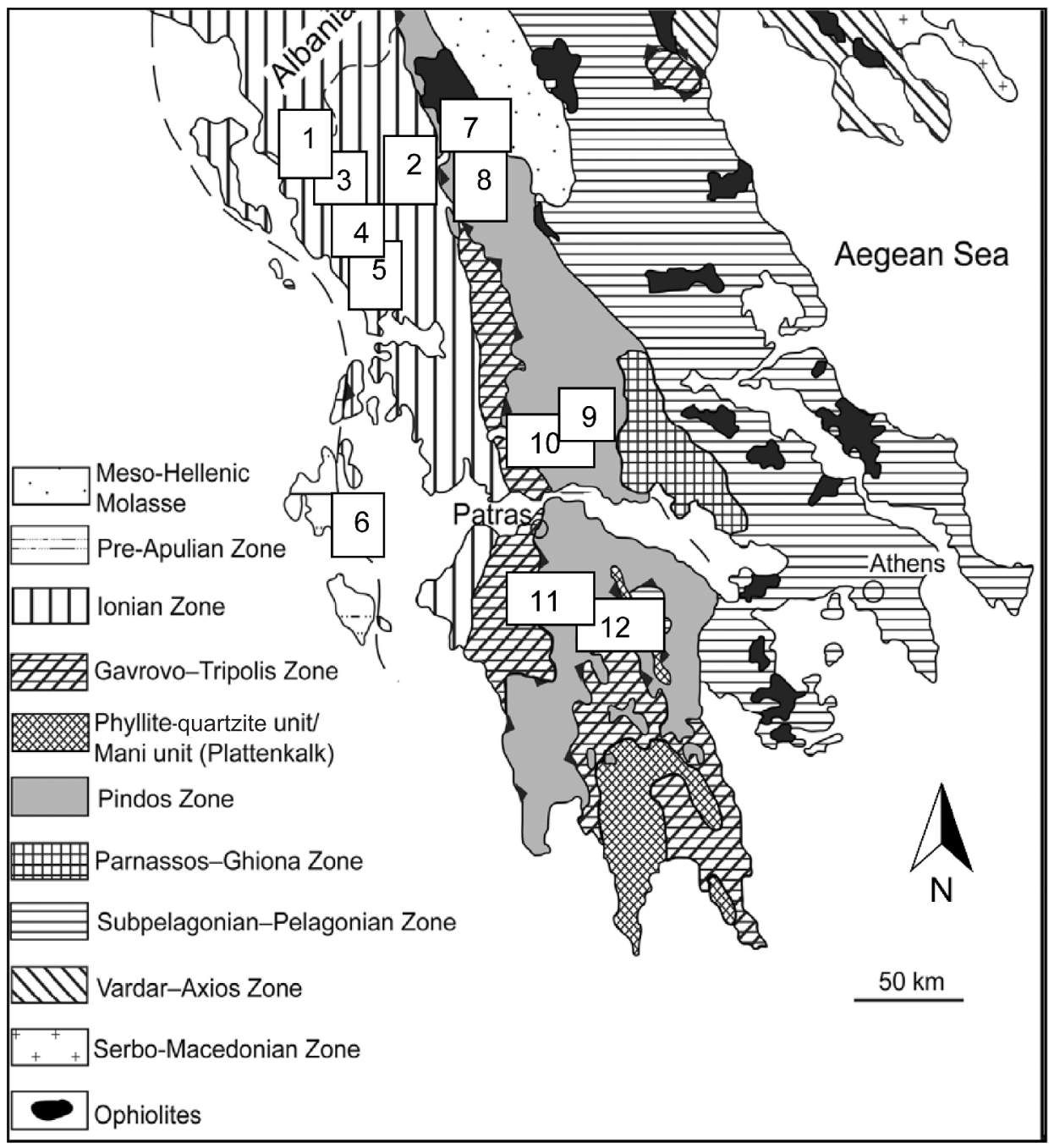

Fig. 3. Geological sketch map of central Greece where sites of black shales are shown

Mainly they belong to the Mesozoic Era (modified from Kafousia et al., 2011); Ionian Zone sites: 1 - Gotzikas, 2 - Chionistra, 3 - Lithino, 4 - Petoussi, 5 - Toka, 6 - Poros; Olonos-Pindos sites: 7 - Sirako, 8 - Kalarites, 9 - Proussos, 10 - Panetoliko, 11 - Livartzi, 12 - Kastelli 
clayey deposits. The Gavrovo Zone was a shallow-water platform during the Triassic to Late Eocene, from which no organic matter-rich deposits have so far been found (Karakitsios, 2013)

The most important locations with Jurassic to Neogene formations which host conventional hydrocarbons are shown in Figure 1. The same locations may be considered promising areas for the discovery of shale oil and gas. The basic geological parameters characterizing these areas are presented in Table 1.

\section{NORTHEASTERN GREECE BASINS}

Evros Delta-Orestias. The rock formations of these sub-basins in Thrace Region consist mainly of siliciclastic deposits (e.g., conglomerates, sandstones, siltstones) of Oligocene to Pleistocene times, with characteristics of shallow marine and/or deltaic depositional environments. In the upper layers of both sub-basins, lignites and shales rich in organic material, meaning a change in the depositional environment to saline, are found. In both sub-basins, exploratory boreholes for hydrocarbon detection were carried out. The depth of the boreholes ranges from 2,100 to $3,700 \mathrm{~m}$. In all the boreholes, biogenic methane was detected at shallow depths.

At greater depths (2,170 to $3,050 \mathrm{~m}$ ) of the Orestias sub-basin, gaseous hydrocarbons of catagenic origin, trapped in Oligocene sandstones, were detected. The upper limit of the oil window in this basin is located at 2,100 $\mathrm{m}$ depth. In the Evros
Delta sub-basin, the presence of methane of both biogenic and metagenic origin was detected. It is located within Oligocene to Pliocene lignite units. The geothermal gradient in this basin, $3^{\circ} \mathrm{C} / 100 \mathrm{~m}$, is lower than that of the other sedimentary basins of eastern Greece $\left(>5^{\circ} \mathrm{C} / 100 \mathrm{~m}\right)$, due to the extended magmatic intrusions of the Paleogene. The oil window is restricted to the interval 1,200-2,400 m (Rigakis et al., 2001; IGMEM, 2012).

In adjacent European Turkey (eastern Thrace), the exploitation of shale gas is pending.

Lemnos Island. This is a unique site in the north Aegean Sea, with Paleogene formations. The creation of Lemnos Basin is placed in the Middle Eocene, when it received the first sediments of this age. The depositional environment was initially terrestrial and then shallow marine, with deposits of nummulitic limestone, which evolved to pelagic. During the Late Eocene to Early Oligocene, an advancing clastic system developed with deposits of typical continental slope. The deposited sediments are comprised of thick-bedded sandstones and conglomerates, with intercalations of silts and clays in the form of turbidites. South of Lemnos, a borehole (LE-1, 2,250 m depth) was drilled and the deposits drilled reached Middle Eocene (IGMEM, 2012).

Shale and clay samples from the Late Eocene to Early Oligocene submarine fans, slope, and shelf of Lemnos Island present poor to excellent source-rock gas potential. In particular, the shales can be classified principally as secondary source rocks with great potential to generate gas. The TOC ranges from 0.01 to $5.04 \%$ with an average value of $1.12 \%$. The organic material in most of the samples is composed of type III

Basic geological parameters characterizing the promising areas of Greece for the discovery of shale gas and shale oil ${ }^{\star}$

\begin{tabular}{|c|c|c|c|c|c|c|c|c|}
\hline $\begin{array}{l}\text { Sedimentary } \\
\text { basin }\end{array}$ & Source rocks age & Lithology & $\begin{array}{l}\text { OM } \\
\text { type }\end{array}$ & $\begin{array}{l}\text { TOC } \\
\text { [wt.\%] }\end{array}$ & $\begin{array}{c}\text { Burial } \\
\text { depth [m] }\end{array}$ & $\begin{array}{c}\text { Source rocks } \\
\text { net thickness } \\
{[\mathrm{m}]}\end{array}$ & $\begin{array}{c}\text { Thermal } \\
\text { maturity } \\
\text { [Ro] }\end{array}$ & $\mathrm{HP}$ \\
\hline $\begin{array}{l}\text { Evros } \\
\text { Delta-Orestias }\end{array}$ & $\begin{array}{l}\text { Pliocene-Pleistocene } \\
\text { Oligocene-Miocene }\end{array}$ & $\begin{array}{c}\text { shales } \\
\text { sandstones-siltstones }\end{array}$ & $\begin{array}{l}\text { n.d. } \\
\text { n.d. }\end{array}$ & $\begin{array}{l}\text { n.d. } \\
\text { n.d. }\end{array}$ & $\begin{array}{l}2,750 \\
3,700 \\
\end{array}$ & $\begin{array}{l}\text { n.d. } \\
\text { n.d. }\end{array}$ & $\begin{array}{l}\text { n.d. } \\
\text { n.d. }\end{array}$ & $\begin{array}{l}\text { gas } \\
\text { gas }\end{array}$ \\
\hline $\begin{array}{l}\text { Lemnos } \\
\text { Island }\end{array}$ & U. Eocene-L. Oligocene & shales-clays & III to IV & $0.1-5.0$ & 2,250 & n.d. & n.d. & gas \\
\hline $\begin{array}{l}\text { Kavala-Prinos } \\
\text {-Nestos Delta }\end{array}$ & M.-U. Miocene & claystones & II to III & $1.2-3.9$ & 3,500 & 10 & 1.10 & oil-gas \\
\hline $\begin{array}{l}\text { Epanomi- } \\
\text { Thermaikos } \\
\text { Gulf }\end{array}$ & Eocene-Oligocene & shales & I to II & n.d. & 2,100 & n.d. & n.d. & gas \\
\hline $\begin{array}{l}\text { Mesohellenic } \\
\text { Basin }\end{array}$ & $\begin{array}{c}\text { Oligocene-Miocene: } \\
\text { Eptachori-Pentalophos } \\
\text { Form. } \\
\text { Eocene-Oligocene: } \\
\text { Krania-Eptachori } \\
\text { Formation }\end{array}$ & $\begin{array}{l}\text { sandstones with shale beds } \\
\text { sandstones with shale } \\
\text { beds }\end{array}$ & $\begin{array}{l}\text { II to III } \\
\text { III }\end{array}$ & $\begin{array}{l}0.4-5.0 \\
0.2-1.5\end{array}$ & $\begin{array}{l}3,200 \\
4,200\end{array}$ & $\begin{array}{l}\text { n.d. } \\
\text { n.d. }\end{array}$ & $\begin{array}{l}0.3-0.6 \\
0.3-0.6\end{array}$ & $\begin{array}{l}\text { gas-oil } \\
\text { gas-oil }\end{array}$ \\
\hline $\begin{array}{l}\text { Western } \\
\text { Greece } \\
\text { (lonian Zone) }\end{array}$ & $\begin{array}{c}\text { Pliocene-Pleistocene } \\
\text { U. Miocene-L. Pliocene }{ }^{1} \\
\text { L. Oligocene-- } \\
\text { M. Miocene } \\
\text { U. Oligocene-M. Miocene } \\
\text { L.-U. Cretaceous } \\
\text { M.-U. Jurassic } \\
\text { L. Jurassic } \\
\text { Triassic } \\
\end{array}$ & \begin{tabular}{|} 
sandstones with clay beds \\
mudstones \\
mudstones \\
mudstones \\
limestones with shale beds \\
cherty clays \\
marls-marly limestones \\
breccias with shale beds \\
\end{tabular} & $\begin{array}{l}\text { I to II } \\
\text { II to III } \\
\text { III } \\
\text { I to II } \\
\text { I to II } \\
\text { I to II } \\
\text { I to II } \\
\text { I }\end{array}$ & $\begin{array}{c}\text { n.d. } \\
0.2-9.2 \\
0.6-32.5 \\
\text { n.d. } \\
0.9-5.0 \\
1.0-3.3 \\
1.0-19.1 \\
0.5-16.1 \\
\end{array}$ & $\begin{array}{l}2,000 \\
\text { n.d. } \\
\text { n.d. } \\
\text { n.d. } \\
\text { n.d. } \\
\text { n.d. } \\
\text { n.d. } \\
\text { n.d. }\end{array}$ & $\begin{array}{c}\text { n.d. } \\
\text { n.d. } \\
\text { n.d. } \\
\text { n.d. } \\
10-65 \\
10-140 \\
10-150 \\
<1 \\
\end{array}$ & $\begin{array}{l}0.6-1.0 \\
\text { n.d. } \\
\text { n.d. } \\
0.6-1.0 \\
0.6-1.0 \\
0.6-1.0 \\
0.6-1.0 \\
0.6-1.0 \\
\end{array}$ & $\begin{array}{l}\text { gas } \\
\text { gas-oil } \\
\text { oil } \\
\text { gas } \\
\text { gas } \\
\text { gas } \\
\text { gas } \\
\text { oil-gas }\end{array}$ \\
\hline $\begin{array}{l}\text { Western } \\
\text { Greece } \\
\text { Pre-Apulian } \\
\text { (Paxi) Zone }\end{array}$ & $\begin{array}{c}\text { Miocene-Pliocene } \\
\text { U. Jurassic } \\
\text { L. Jurassic (4 horizons) }\end{array}$ & $\begin{array}{l}\text { marls-clastic sediments } \\
\text { marly limestones } \\
\text { marls-marly limestones }\end{array}$ & $\begin{array}{l}\text { III } \\
\text { I to II } \\
\text { II to III }\end{array}$ & $\begin{array}{c}\text { n.d. } \\
0.6-11.2 \\
0.6 \text { av. }\end{array}$ & $\begin{array}{l}1,850-3,260 \\
1,850-3,250\end{array}$ & $\begin{array}{l}\text { n.d. } \\
>200 \\
\text { n.d. }\end{array}$ & $\begin{array}{l}1.0-2.0 \\
0.6-1.0 \\
0.6-2.0\end{array}$ & $\begin{array}{c}\text { oil } \\
\text { gas } \\
\text { gas-oil }\end{array}$ \\
\hline
\end{tabular}

*- the relative references are presented in the text; OM - Organic Matter, TOC - Total Organic Carbon, HP - Hydrocarbon Prospectivity, n.d. no data, ${ }^{1}-$ Zakynthos Island, ${ }^{2}-$ Diapondia islands 
kerogen, which is suitable for gas production. Organic matter composed of type IV kerogen has been detected in a few samples. Only one sample is composed of type I kerogen, which is suitable for oil production. The shales and clays studied are mainly of the immature oil stage. Additional geochemical measurements, such as spore-colour index and determination of biomarker parameters, are required (Maravelis, 2009).

Kavala-Prinos-Nestos Delta. The development of this basin started during the Miocene, when terrestrial deposits (e.g., pebbles, sands, silts and clays) were deposited in a restricted hyper-saline environment. Organic materials, intercalated with clastics and carbonates, followed. They were overlain by turbidites that correspond to the hydrocarbon reservoirs, and these by thick evaporite layers of the Messinian, due to the dry climate and isolation of the basin. The sedimentation continued with clastic marine deposits during the Pliocene-Holocene. The continuous sedimentation and gradual subsidence of the basin resulted in a thick sediment formation of about $5.8 \mathrm{~km}$. The deepest parts of the basin reached adequate thermal maturity for hydrocarbon generation (Pollak, 1979; Proedrou, 1979, 1988; Georgakopoulos, 1998, 2000).

Marine claystones of the Middle to Upper Miocene, deposited under highly reducing conditions and interrupted by hypersaline episodes, are considered the source rocks of oil and gas in this basin (Fig. 4). The claystones are characterized by a waxy sapropelic oil-prone kerogen with terrestrially-derived organic matter frequently dominant. The organic matter belongs to the types II and III of kerogen. TOC values vary from 1.20 to $3.90 \%$. Maturity measurements show vitrinite reflectance up to 1.10 for depths up to $3,500 \mathrm{~m}$ (Proedrou and Papaconstantinou, 2004).

Since 1981, the exploitation of oil and gas has taken place here. In the southern part of the taphrogenic basin (area of Prinos), the gas deposit is hosted in fine- to coarse-grained sandstones and conglomerates alternating with clays and marls. The deposit is intercalated between two evaporitic horizons, and is found at a depth of 1,660-1,720 m, with net thickness $10 \mathrm{~m}$, porosity ranging from 10 to $24 \%$, and transmittance up to $400 \mathrm{md}$. The in place reserves are estimated at 1 billion $\mathrm{m}^{3}$. The production until 2010 was 0.9 billion $\mathrm{m}^{3}$ of gas and 120 million barrels of oil. Gases are also detected in the oil wells of the Prinos oil field. The natural gas of the Prinos sub-basin is too mature, as it is concluded by its high $\mathrm{H}_{2} \mathrm{~S}$ content and isotopic data. The gas in the south Kavala sub-basin is less mature than that of Prinos. The gases from both sites are of catagenic origin (Rigakis et al., 2001; IGMEM, 2012).

Three deep wells, drilled in the Nestos Delta sub-basin for oil exploration, identified very promising gas horizons (from 1,820 to $2,770 \mathrm{~m}$ ) of catagenic origin within sandstone layers of Miocene times. At shallow depths the gas is methane, obviously of biogenic origin. Most of this gas is related to lignite horizons of significant thicknesses (Rigakis et al., 2001).

A detailed analysis of samples (especially fine-grained sandstones and shales) of Miocene age, selected from boreholes and cuttings (1,780-3,550 m depth) of the Nestos River Delta, showed that these deposits have been subjected to low temperatures $\left(65-110^{\circ} \mathrm{C}\right)$ and that the gaseous and liquid hydrocarbons in them are limited. The low hydrocarbon content is due to (Tsirambides and Soldatos, 1989):

- the limited presence of fine-grained clastic deposits, which are considered source rocks for the formation of hydrocarbons;

- the migration of these products to adjacent reservoirs with clastic deposits of significant porosity (e.g., the
Kavala-Prinos Basin), because of the intense tectonic activity in the area during the Neogene and Quaternary.

Epanomi-Thermaikos Gulf. In the Epanomi sub-basin, two exploration boreholes (depth 2,470-2,800 m) carried out on land detected a small gas field, which during the tests gave a maximum gas production of $19 \times 106 \mathrm{cf} /$ day and a small quantity of light oil in deeper formations. The gas is trapped in Upper Jurassic to Lower Cretaceous limestone with $1 \%$ average porosity. The chemical composition (wt.\%) of this gas is (Roussos, 1993):

\begin{tabular}{|c|c|c|c|c|c|c|c|c|c|}
\hline $\mathrm{CO}_{2}$ & $\mathrm{~N}_{2}$ & $\mathrm{C} 1$ & $\mathrm{C} 2$ & $\mathrm{C} 3$ & $\mathrm{iC} 4$ & $\mathrm{nC} 4$ & $\mathrm{iC} 5$ & $\mathrm{nC} 5$ & $\mathrm{C} 6+$ \\
\hline 23 & 7.2 & 66.2 & 1.9 & 0.8 & 0.2 & 0.2 & 0.1 & 0.1 & 0.3 \\
\hline
\end{tabular}

The Epanomi gas is mainly of catagenic origin and may be characterized as wet gas, since it contains a significant percentage of $\mathrm{C} 2+$ compounds (3.2-4.0\%). The minimum reserves in place are $500 \times 106 \mathrm{~m}^{3}$ (Roussos, 1993). The deposit has a dual origin: one source may be considered the Eocene shales of the adjacent Posidi area (POS-1 borehole) about $40 \mathrm{~km} \mathrm{SE}$ of Epanomi. The organic matter in these shales derives from algae and higher plants, so this gas is considered of catagenic origin. A second source is considered to have ascended from deeper levels, as shown by the high level of maturity of organic matter contained therein. This gas is of thermogenic origin. The gas field of Epanomi is the first discovery of such a gas deposit in the Paleogene land basins of northern Greece. Its relatively small size is mainly due to the very low porosity of the reservoir (Roussos, 1993; Rigakis et al., 2001).

In the Thermaikos Gulf sub-basin, two boreholes (depth 1,180-3,500 m) were drilled and very significant gas accumulations were detected. At shallow depths, dry gas of biogenic origin was identified in sandstone layers. This gas is related to lignite units of Miocene to Pleistocene age. At deeper layers, wet gas of catagenic origin was detected and is related to Eocene to Miocene lignites. This categenic gas has a similar composition and probably the same source as the Epanomi gas. The identification of source rocks, the certification of maturity, and the potential of these rocks for the production of gaseous and liquid hydrocarbons, as well as the favourable conditions of their migration, directed the investigations to identify suitable traps in the lower members of the molasse deposits of this basin. The supply of the gas deposit occurs laterally in the deeper parts of the basin from Eocene source rocks (Rigakis et al., 2001).

\section{NORTH-CENTRAL GREECE}

Mesohellenic Basin (Fig. 3). This is a piggy-back basin of the Hellenides Orogen, located in north-central Greece. It is 130 $\mathrm{km}$ long and $40 \mathrm{~km}$ wide and trends NNW-SSE. It comprises two depocentres, the first one in the north $(3,200 \mathrm{~m}$ thick), and the second in the south $(4,200 \mathrm{~m}$ thick). The basin developed from the Late Eocene to Late Miocene and is filled with coarseto fine-grained deposits. The sedimentary sequences consist mainly of submarine fan (sandstone and shale) and deltaic deposits, which accumulated unconformably over an ophiolite complex. The hydrocarbon potential is indicated by the presence of kerogen types II/III with minor amounts of type I. The evidence is mostly for wet and dry gas, with minor oil. Source rocks are the Middle Eocene to Lower Oligocene Krania and Eptachori formations, of up to 2,000 $\mathrm{m}$ in total thickness, which reached maturation during the Early Miocene. The source rocks 
consist of outer fan and basin plain deposits. They are conformably overlain by the lower member (Late Oligocene) of the up to 2,600 m thick Pentalophos Formation, which consists mostly of thick submarine sandstone lobes. Possible stratigraphically-trapped reservoirs include the lower member of the Pentalophos Formation, which overlies source rocks, as well as limestones tectonically intercalated within the ophiolite complex, underlying the source rocks. The main features of this basin are the thermal immaturity of the contained organic matter and the existence of limited potential source rocks, having reached the very early stage of "oil maturity" (Kontopoulos et al., 1999; Rigakis et al., 2001; Avramidis and Zelilidis, 2007).

\section{WESTERN GREECE BASINS}

NW of Diapondia islands (north of the Borsh-Khardhiqit strike-slip fault). This basin lies on the pre-Apulian Zone and was formed following the lonian thrust movements of $80 \mathrm{~km}$ eastwards, close to the Albania coast. It is considered analogous to the Durres Basin of Albania and is filled by deposits of great thickness. The area potentially hosts two hydrocarbon systems: a Neogene one and, more speculatively, a Mesozoic one. The Neogene hydrocarbon system consists of Tortonian shales that may comprise potential source rocks, while Tortonian-Messinian sandstones may comprise the reservoirs. These may be sealed by Messinian evaporites (as it happens in the Durres Basin). The Mesozoic hydrocarbon system is mainly attributed to the MidMesozoic hydrocarbon system in Greece and Albania, with comparable source potential and maturation profiles. Structural traps may be present, while traps formed by compressive tectonic processes may also occur. Because of the continuous development of the lonian thrust belt, the compressive tectonic regime may lead to the development of major compressional anticlines (Maravelis et al., 2012).

Diapondia islands (lonian thrust piggy-back basin). The Lower Oligocene to Middle Miocene slope succession in the western part of the Hellenic Fold and Thrust Belt (FTB) on the Diapondia islands (Ionian Sea) was studied to evaluate its source rock potential for hydrocarbon discovery. Geochemical data indicated that organic matter is present in sufficient abundance and in good enough quality in the drilled mudstones to be regarded as potential source rock. The Rock-Eval II pyrolytic yields and the calculated values of hydrogen and oxygen indices indicate that the organic matter is of type III kerogen. The rock succession is immature with respect to oil generation and has not experienced high temperature during burial. However, its eastern downslope equivalent deep-sea mudstone facies should be considered as good gas-prone source rock onshore, since they may have experienced higher thermal evolution. In addition, they may have improved organic geochemical parameters because the organic matter is not oxidized. TOC content is the primary parameter for source rock appraisal, with a threshold of $1 \%$ at the immature stage for potential source rocks. With average TOC values close to this lower limit $(0.96 \%)$ and the occurrence of samples exceeding this threshold (up to $32.5 \%$ ), the mudstones studied may be considered potential source rocks. Such TOC values indicate that sediment emplacement occurred under conditions favourable for organic matter preservation related to short distance transportation and deposition in a rather low water depth (Maravelis et al., 2014).

Ionian thrust foreland basin (IFB). The basin, lying on the pre-Apulian Zone, is asymmetrical with maximum subsidence occurring towards the thrust complex. Potential hydrocarbon source rocks in the IFB are mostly pelagic deposits rich in marine organic material, although terrigenous organic matter is found in the clastic deposits of Miocene to Pleistocene age. Hydrocarbons in this basin are present within the rock formations of:

- Pliocene,

- Miocene,

- Late Jurassic,

- Middle Jurassic bituminous shales,

- Triassic black shales (Karakitsios and Rigakis, 2007).

Porosity measurements were carried out on surface samples of various formations in the IFB, and porosity deduced from electrical logs indicate moderate reservoir quality accompanied

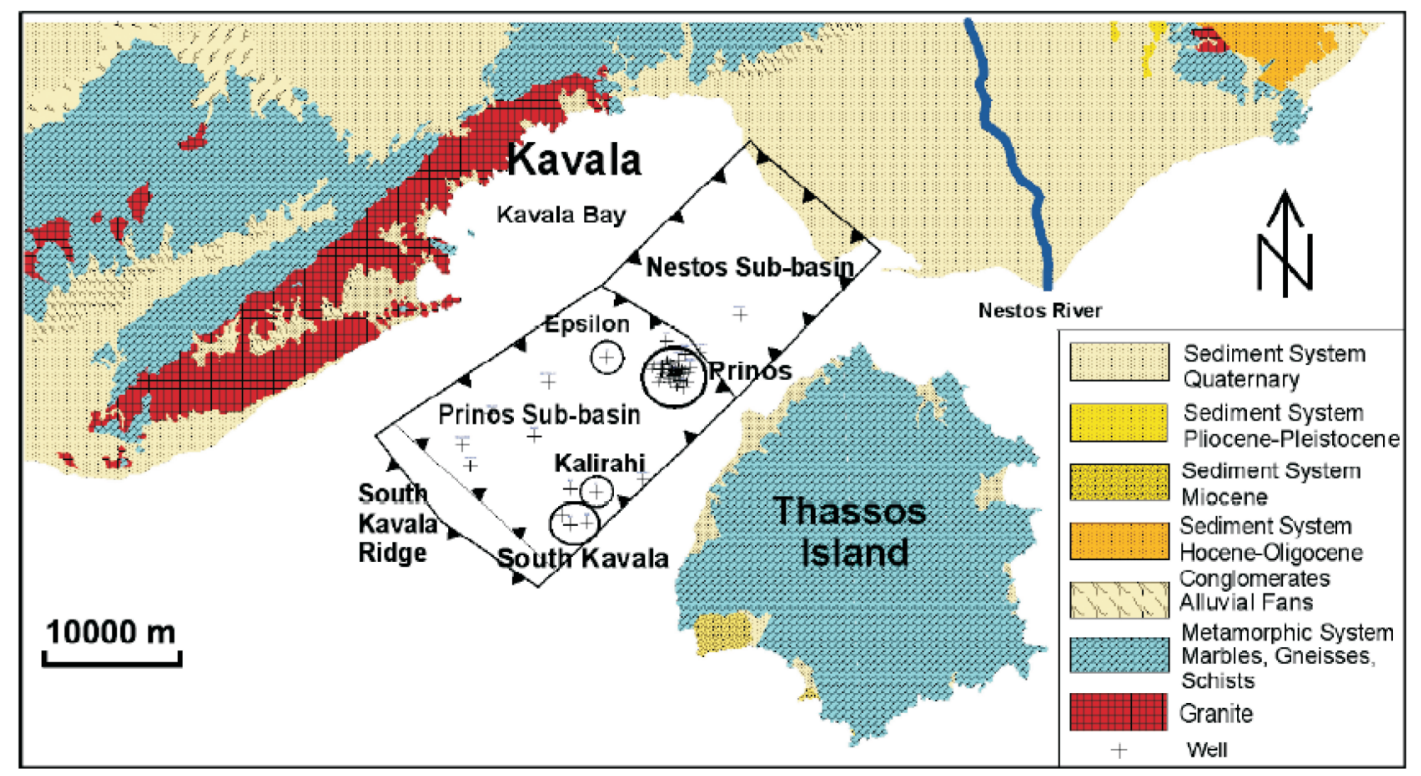

Fig. 4. Kavala-Prinos hydrocarbon field with its two sub-basins (Kiomourtzi et al., 2008) 
by low permeabilities. In pelagic facies rocks, porosity and permeability are even lower. The continuous development of the Ionian thrust belt led to the development of major compressional, roll-over anticlines that may form large-scale structural traps. In addition, tilted fault blocks may also lead to the oil/gas entrapment (Maravelis et al., 2012).

Preveza Basin. This basin was mostly formed in the preApulian (Paxi) Zone and was influenced by the local strike-slip movement of the Cephalonia transform fault. The accumulated deposits were strongly influenced by the lonian thrust. They comprise the thick sedimentary formations of the Preveza Basin which increase in thickness southwards, and towards the Cephalonia fault. Hydrocarbon source rocks in the Preveza Basin may constitute the Tortonian shales. Tortonian-Messinian sandstones are able to constitute ideal reservoirs, sealed by Messinian evaporites. Structural traps derived from the CephaIonia transform fault activity may exist, while Pleistocene strikeslip faults, accommodated by thrusts and folds, may act as structural traps too. Additionally, footwall and hanging wall traps, such as tightly-folded anticlines sealed by shale and anhydrite, related to folding and thrusting, may also occur (Maravelis et al., 2012).

Zakynthos Island. Organic geochemical analysis of Upper Miocene-Lower Pliocene mudstones from the southwestern edge of the Hellenic FTB (Zakynthos Island) led to the establishment of a system with gaseous source rock potential. This study also enabled the analysis of their characteristics in terms of the total organic matter content, and its type, quality, and maturity level, together with the analysis of their generating potential. The study region contains rock formations that are worthy of further consideration (TOC 0.2-9.2\%). Rock-Eval values reveal the occurrence of source rocks with fair to excellent hydrocarbon-generating potential. The studied organic-rich facies from one section are oil-prone, whereas the kerogen in all other sections is gas-prone. The GC-MS data, which is a direct indicator of the types of hydrocarbons that can be generated by the kerogen during the maturation process, indicate that all the deposits studied are gas-prone. Maturity data suggest that the section studied is thermally immature. Even though the rocks investigated have sufficient TOC content and SP values and contain gas-prone organic material, they have not attained adequate thermal maturity. These facies might have matured sufficiently to enter the oil generation zone where they are more deeply buried (Maravelis et al., 2015).

Peloponnesus basins. The area of Katakolo is built from the bedrock of Alpine strata of the lonian and Gavrovo zones, of Paleogene flysch, and of deposits of the Neogene and Quaternary. From boreholes carried out on land to detect the presence of hydrocarbons, a small gas field was found (depth $1,230-1,760 \mathrm{~m}$ ) trapped in medium- to fine-grained sandstones. This gas will be able to meet local needs. In addition, shallow biogenic gas accumulations in Neogene sandstones have also been revealed. Horizons of lignites with high contents of organic matter have been considered to be the source rock of this gas. The oil reservoir is located at a depth of 2,400-2,600 m (Kamberis et al., 2000; Rigakis et al., 2001).

The Pindos foreland basin in western Peloponnesus involves three narrow linear sub-basins (e.g., Tritea, Hrisovitsi, and Finikounda), the result of internal thrust activity. This activity produced intra-basinal basement highs, which were crosscut by transfer faults and created pathways for the transportation of coarser material in the distal parts of these sub-basins. The transfer fault zones contain complex structural geometries that could make them optimal locations for structural hydrocarbon traps and reservoirs. The Eocene-Oligocene deposits are thicker and sand-rich on the downthrown sides of the transfer faults. In these areas, sandstone reservoirs could be present on the marginal blocks or in deep troughs resulting from the accumulation of deep-water turbidites. Such tectonically active areas constitute promising oil and gas reservoirs and traps (Konstantopoulos et al., 2013).

Gaseous hydrocarbons were detected in most boreholes offshore of NW Peloponnesus. These gas concentrations, mainly of methane, are hosted in the clastic horizons of the Upper Neogene or in Mesozoic carbonates and are separated into two categories: dry and wet gas, possibly of mixed origins (biogenic and catagenic). The gas is found in deposits of the Plio-Pleistocene and is located at shallow depths $(<2,000 \mathrm{~m})$. Here the geothermal gradient varies from $1.15^{\circ} \mathrm{C} / 100 \mathrm{~m}$ in the evaporites up to $2^{\circ} \mathrm{C} / 100 \mathrm{~m}$ in the clastic and carbonate deposits. The biogenic gases are associated with the presence of lignite horizons and they are too immature for oil genesis (Rigakis et al., 2001).

\section{METHANE HYDRATES}

While global estimates vary considerably, the energy content of methane occurring in hydrate form is immense, possibly exceeding the combined energy content of all other known fossil fuels. Mud volcanoes (MVs) are also known for their high methane fluxes, ascending methane-rich fluids from the seafloor, gas hydrates, and favourable environments for chemosynthetic symbiotic fauna. Active MVs are associated, throughout the world, with hydrocarbon occurrences (Timor, South Caspian Sea, the Caribbean, Egypt and Cyprus). However, future production volumes are speculative because methane production from hydrates has not been documented beyond small-scale field experiments (Woodside et al., 1998; Aksu et al., 2009; Lykousis et al., 2009; Perissoratis et al., 2011; Foscolos et al., 2012).

The occurrence of MVs, mud diapirs, and fluid seeps has long been known in various different geological environments of the eastern Mediterranean and thus in the southern Aegean Sea. They occur not only in regions of compressional stress in subduction zones (e.g., Calabrian Arc, Mediterranean Ridge, and other submarine orogenic belts), but also on passive rifted margins such as the Egyptian offshore and areas of mixed tectonic signature like the Anaximander Mountains. Here the mud volcanism is related to faults with normal and transcurrent faulting components. The accretionary prism of the Hellenic Arc (part of the Mediterranean Ridge) is an area where a large number of mud volcanoes have been studied following their discovery in the late 1970s. MVs within the Greek Exclusive Economic Zone (EEZ) have been emitting natural gas bubbles for more than one million years. The area covered by the gas hydrates is about $200,000 \mathrm{~km}^{2}$ and the volume is roughly calculated at 30 trillion $\mathrm{m}^{3}$, assuming an average thickness of $150 \mathrm{~m}$. Roughly, $1 \%$ of this volume is found in the form of methane hydrates: that is 0.30 trillion $\mathrm{m}^{3}$. This amount should be multiplied by $170 \mathrm{~m}^{3}$ of natural gas $/ 1 \mathrm{~m}^{3}$ of hydrate in order to equate it to the conventional natural gas reserves. This implies that in the Greek EEZ, 51 trillion $\mathrm{m}^{3}$ of natural gas exists. This is equivalent to 328 billion barrels of oil, which is a huge amount (Foscolos et al., 2012). However, this assumption seems exaggerated.

The Anaximander Mountains are situated between the Hellenic and Cyprus Arcs (Fig. 5) at sea water depths of $1,500-2,500 \mathrm{~m}$. Their setting is clearly favourable for the occurrence of mud volcanoes because of the presence of over-pressured fluids and faults that act as conduits for the fluids to es- 


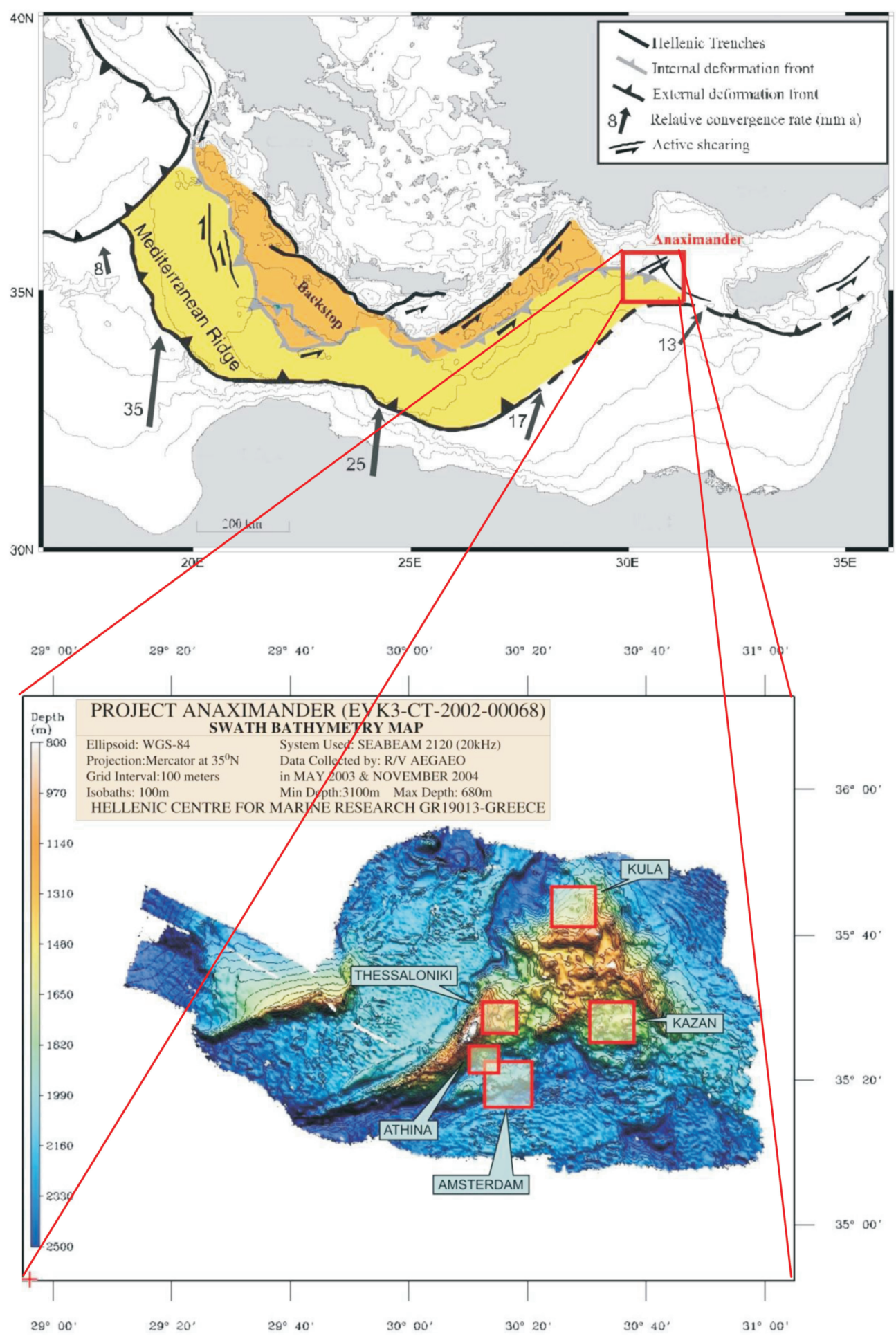

Fig. 5. Anaximander Mountains with the main mud volcanoes (MVs) (Lykousis et al., 2009)

cape (Ten Veen et al., 2004). Discovered during the Dutch ANAXIPROBE project by multi-beam surveying in 1995, seven large mud volcanoes were sampled in 1996 when the first gas hydrate samples in the Mediterranean Sea were collected from Kula MV. By 2002, the Amsterdam and Kazan MVs were also discovered to have hydrates. Between 2003 and 2005, the EC-funded project ANAXIMANDER targeted these mud volca- noes in a study of gas hydrates and this was followed by the HERMES project (2005-2009). During these projects, many gas-hydrate samples were collected and studied. Such a sample from the Amsterdam mud volcano showed the prevalence of thermogenic light hydrocarbons, as inferred from $\mathrm{C} 1 / \mathrm{C} 2+$ ratios and isotopic data (Pape et al., 2010). 
The area covered by the gas hydrates at Anaximander Mountains is about $46 \mathrm{~km}^{2}$ and the volume of methane is estimated at 2.6-6.4 trillion $\mathrm{m}^{3}$. The sea bottom water temperature is $13.7^{\circ} \mathrm{C}$ and the mean regional geothermal gradient $30^{\circ} \mathrm{C} / \mathrm{km}$. Methane hydrates are present, usually deeper than $0.4 \mathrm{~m}$ from the seabed surface. Their texture resembles compacted snow and their external morphology resembles flakes or lumps or big ice crystals. Biostratigraphical analyses of mud and rock clasts indicate that they were derived from sedimentary rocks underlying the seabed (Upper Cretaceous limestones, Paleocene siliciclastic rocks, Eocene biogenic limestones, and Miocene mudstones; Lykousis et al., 2009).

\section{COAL-BED GAS}

Coal-bed gas is methane-rich gas occurring in self-sourcing reservoirs in undeveloped coal-beds and worked coal-seams. Although the USA, Canada, and Australia are the only significant coal-bed gas producers, coalmine methane is produced in another 13 coal-producing countries. Coalmine gas production has a dual purpose: to remove methane as a safety measure, and to capture vented methane because of its severe impact as a greenhouse gas.

The quality characteristics of the 14 most important coal-basins of Greece, on an "as-received" basis, are: 9-66\% moisture, $16-33 \%$ volatile matter, $8-28 \%$ fixed carbon content, $10-43 \%$ ash, $0.1-4 \%$ sulphur, and $4-15 \mathrm{MJ} / \mathrm{kg}$ calorific value. Methane content is $<3 \%$. The large variations of these constituents in the basins, as well as within each basin, are attributed to the age, nature of occurrence (multilayer deposits), environment of deposition, and the geological setting (Papanicolaou et al., 2005; Tsirambides, 2005).
The low content in gaseous hydrocarbons and the widespread tectonics across the whole Hellenic Peninsula are the main factors which prevented large gas accumulations in the coal deposits. However, additional research is needed to evaluate the coal-bed gas potential of the country.

\section{CONCLUSIONS}

The unconventional hydrocarbons potential of Greece is unknown as long as detailed investigations are lacking.

Exploration for conventional hydrocarbon reservoirs, through the interpretation of seismic profiles and surface geological data, will simultaneously provide the subsurface geometry of the unconventional ones. Their exploration should follow that of conventional hydrocarbons.

Today, because the interest of many of the major oil companies is directed to unconventional sources of energy, Greece needs re-evaluation of the data from all boreholes carried out, on the basis of new information, with the aim to identify possible reserves of unconventional hydrocarbons retained in highly compacted fine-grained deposits.

In addition to the large financial interest in the use of these unconventional sources of energy, there is currently no national or European Union legislative framework which deals with the mining issues and environmental impacts.

Acknowledgements. I am grateful for the inspiring notes of the four referees $(H$. Kiersnowski, A. Georgakopoulos, V. Karakitsios, and J. Golonka), as well as those of the editors and J. Zalasiewicz. Their detailed reviews and corrections improved my manuscript greatly.

\section{REFERENCES}

Aksu, A., Hall, J., Yaltirak, C., 2009. Miocene-recent evolution of Anaximander Mountains and Finike Basin at the junction of Hellenic and Cyprus Arcs, eastern Mediterranean. Marine Geology, 258: 24-47.

Avramidis, P., Zelilidis, A., 2007. Potential source rocks, organic geochemistry and thermal maturation in the southern depocenter (Kipourio-Grevena) of the Mesohellenic Basin, central Greece. International Journal of Coal Geology, 71: 554-567.

Foscolos, A., Konophagos, E., Bruneton, A., 2012. The occurrence of converging plates, mud flow volcanoes and accretionary prism complexes in the Mediterranean Ridge. Their relationship to possible hydrocarbon accumulations offshore Crete. A new perspective for oil and natural gas resources of Greece. Mineral Wealth, 165: 7-26.

Georgakopoulos, A., 1998. Organic geochemical study of Greek oil source rocks. In: Proceedings of the 2nd International Conference and Technical Exhibition "Modern Exploration and Improved Oil and Gas Recovery Methods". East Meets West, Kraków, Poland: 208-213.

Georgakopoulos, A., 2000. Lithology and stratigraphy of the Neogene Prinos-Kavala basin, Northern Greece. Geological Society of Greece, Special Publication, 9: 79-84.

IGMEM, 2012. Preliminary geological study of possibilities and perspectives of localization of probable geological formations of shale gas and bituminous shales in Greece (in Greek). Internal report, Athens.
Kafousia, N., Karakitsios, V., Jenkyns, H.C., Mattioli, E., 2011. A global event with a regional character: the Early Toarcian Oceanic Anoxic Event in the Pindos Ocean (northern Peloponnese, Greece). Geological Magazine, 148: 619-631.

Kamberis, E., Rigakis, N., Tsaila-Monopolis, S., loakim, Chr., Sotiropoulos, S., 2000. Shallow biogenic gas-accumulations in Late Cenozoic sands of Katakolon peninsula, Western Greece. Geological Society of Greece, Special Publication, 9: 121-138.

Karakitsios, V., 2013. Western Greece and Ionian Sea petroleum systems. AAPG Bulletin, 97: 1567-1595.

Karakitsios, V., Rigakis, N. 2007. Evolution and petroleum potential of western Greece. Journal of Petroleum Geology, 30: 197-218.

Kiomourtzi, P., Pasadakis, N., Zelilidis, A., 2008. Source rock and depositional environment study of three hydrocarbon fields in Prinos-Kavala Basin (North Aegean). Open Petroleum Engineering Journal, 1: 16-29.

Konstantopoulos, P., Maravelis, A., Zelilidis, A., 2013. The implication of transfer faults in foreland basin evolution: application on Pindos foreland basin, West Peloponnesus, Greece. Terra Nova, 25: 323-336.

Kontopoulos, N., Fokianou, T., Zelilidis, A., Alexiadis, C., Rigakis, N., 1999. Hydrocarbon potential of the middle Eocene-middle Miocene Mesohellenic piggy-back basin (central Greece): a case study. Marine and Petroleum Geology, 16: 811-824. 
Koukouzas, C., Foscolos, A., Kotis, T., 1997. Research and exploration of coal in Greece: A view to the future. Energy Sources, 19: 335-347.

Le Pichon, X., Lybtris, N., Angelier, J., Renard, V., 1982. Strain distribution over the East Mediterranean Ridge: a synthesis incorporating new Sea-Beam data. Tectonophysics, 86: 243-274.

Lykousis, V., Alexandri, S., Woodside, J., De Lange, G., DähImann, A., Perissoratis, C., Heeschen, K., Ioakim, Chr., Sakellariou, D., Nomikou, P., Rousakis, G., Casas, D., 2009. Mud volcanoes and gas hydrates in the Anaximander Mountains (Eastern Mediterranean Sea). Marine and Petroleum Geology, 26: 854-872.

Maravelis, A., 2009. The detailed sedimentological and petrographical research of the flysch deposits on Lemnos Island, NE Greece. Paleogeographic evolution of the NE Aegean Sea with respect to hydrocarbon field formation (in Greek with English abstract). Ph.D. Thesis, University of Patras.

Maravelis, A., Makrodimitris, G., Zelilidis, A., 2012. Hydrocarbon prospectivity in the Apulian platform and Ionian zone, in relation to strike-slip fault zones, foreland and back-thrust basins of Ionian thrust, in Greece. Oil and Gas European Magazine, 38: 64-89.

Maravelis, A., Makrodimitras, G., Pasadakis, N., Zelilidis, A., 2014. Stratigraphic evolution and source rock potential of a Lower Oligocene to Lower-Middle Miocene continental slope system, Hellenic Fold and Thrust Belt, Ionian Sea, northwest Greece. Geological Magazine, 151: 394-413.

Maravelis, A., Koukounya, A., Tserolas, P., Pasadakis, N., Zelilidis, A., 2015. Geochemistry of Upper Miocene-Lower Pliocene source rocks in the Hellenic Fold and Thrust Belt, Zakynthos Island, Ionian Sea, western Greece. Marine and Petroleum Geology (in press).

Marnelis, F., Roussos, N., Rigakis, N., Karakitsios, V., 2007. Structural geology of the Western Greece Fold and Thrust Belt. Guide to Fieldtrip. Energy Conference and Exhibition, AAPG and AAPG European Region, Athens.

Mavromatidis, A., 2009. Review of hydrocarbon prospectivity in the Ionian Basin, Western Greece. Energy Sources, A (31): 619-632.

Mountrakis, D., 2006. Tertiary and Quaternary tectonics of Greece. GSA Special Paper, 409: 125-136.

Papanikolaou, D., 1980. Geotraverse Southern Rhodope-Crete (preliminary results; with the contribution of N. Scarpelis). In: IGCP 5 (ed. F.P. Sassi). Newsletter, 2: 41-48.

Papanicolaou, C., Galetakis, M., Foscolos, A., 2005. Quality Characteristics of Greek Brown Coals and Their Relation to the Applied Exploitation and Utilization Methods. Energy and Fuels, 19: 230-239.

Pape, T., Kasten, S., Zabel, M., Bahr, A., Abegg, F., Hohnberg, H.J., Bohrmann, G., 2010. Gas hydrates in shallow deposits of the Amsterdam mud volcano, Anaximander Mountains, Northeastern Mediterranean Sea. Geo-Marine Letters, 30: 187-206.

Perissoratis, C., loakim, Chr., Alexandri, S., Woodside, J., Nomikou, P., Dählmann, A., Casas, D., Heeschen, K., Amman, H., Rousakis, G., Lykousis, V., 2011. Thessaloniki mud volcano, the shallowest gas hydrate-bearing mud volcano in the Anaximander Mountains, Eastern Mediterranean. Journal of Geological Research, doi: 10.1155/2011/247983

Pollak, W.H., 1979. Structural and lithological development of the Prinos-Kavala basin, sea of Thrace, Greece. Annales Geologiques des Pays Helleniques, II: 1003-1011.

Proedrou, P., 1979. The Evaporites Formation in the Nestos-Prinos Graben in the Northern Aegean Sea. Annales Geologiques des Pays Helleniques, II: 1013-1020.

Proedrou, P., 1988. New age determination of the Prinos Basin. Bulletin of the Geological Society of Greece, 20: 141-147.
Proedrou, P., Papaconstantinou, C., 2004. Prinos Basin - A model for oil exploration. Bulletin of the Geological Society of Greece, 36: 327-333.

Psilovikos, A., Koufos, G., Syrides, G., 1987. The problem of red-beds in Northern Greece. Annals of the Hungarian Geological Institute, 70: 509-516.

Rigakis, N., Roussos, N., Kamberis, E., Proedrou, P., 2001. Hydrocarbon gas accumulations in Greece and their origin. Bulletin of the Geological Society of Greece, 34: 1265-1273.

Rigakis, N., Nikolaou, K., Marnelis, F., Pakos, Th., 2007. The utility of oil shows in the hydrocarbon exploration of western Greece. Bulletin of the Geological Society of Greece, 40: 959-971.

Roussos, N., 1993. The hydrocarbon gas field of Epanomi (Thessaloniki). An example of fractured reservoir (in Greek with English abstract). Bulletin of the Geological Society of Greece, 28: 507-523.

Ślączka, A., Golonka, J., Oszczypko, N., Cieszkowski, M., Słomka, T., Matyasik, I., 2014. Occurrence of Upper Jurassic-Lower Cretaceous black organic-rich pelitic sediments as targets for unconventional hydrocarbon exploration in the Outer Carpathians and adjacent part of the Alps. AAPG Bulletin, 98: 1967-1994.

Ten Veen, J., Woodside, J., Zitter, T., Dumon, J., Mascle, J., Volkonskaia, A., 2004. Neotectonic evolution of the Anaximander Mountains at the junction of the Hellenic and Cyprus arcs. Tectonophysics, 391: 35-65.

Tsirambides, A., 2005. The Mineral Wealth of Greece (in Greek). Yahoudi Publications, Thessaloniki.

Tsirambides, A., Filippidis, A., 2012. Energy Mineral Resources of Greece. Journal of Environmental Science and Engineering, B (1): 709-719

Tsirambides, A., Soldatos, K., 1989. Diagenesis and oil generating potential of Miocene sediments from Nestos delta. Scientific Annals of the School of Geology, Univ. Thessaloniki, 1: 37-48.

Woodside, J., Ivanov, M., Limonov, A., 1998. Shallow gas and gas hydrates in the Anaximander Mountains region, Eastern Mediterranean Sea. Geological Society Special Publications, 137: 177-193.

YPEKA (Ministry of Environment, Energy \& Climate Change), 2011a. International public invitation no. D1/20472/05.09.2011 for the participation in Non-Exclusive Seismic Survey offshore Western and Southern Greece, http://www.ypeka.gr/LinkClick. aspx?fileticket=Q5ohLd0nSIY\%3d\&tabid=768\&language=en-US

YPEKA, 2011b. International call for proposals no. D1/20472/5.9.2011 for participation in the non-exclusive seismic survey off the coasts of western and southern Greece (2011/C 353/09). http://www.ypeka.gr/LinkClick.aspx?fileticket= $17 \mathrm{MsRu} \% 2 \mathrm{bzR} 5 \mathrm{Q} \% 3 \mathrm{~d}$ \&tabid=765\&language $=\mathrm{el}-\mathrm{GR}$

YPEKA, 2012a. Explanatory note for the international public invitation for the participation in non-exclusive seismic survey offshore western and southern Greece (No. D1/20472/05.09.2011). http://www.ypeka.gr/LinkClick.aspx?fileticket $=600 B \% 2 \mathrm{fNeXAv}$ $\mathrm{M} \% 3 \mathrm{~d} \&$ tabid=768\&language $=\mathrm{en}-U S$

YPEKA, 2012b. Open door invitation for granting and using authorizations for the exploration and exploitation of hydrocarbons. http://www.ypeka.gr/LinkClick.aspx?fileticket=Fu3wN2h8Sn $M \% 3 d \&$ tabid=765\&language=en-US

YPEKA, 2014. Notice from the Government of the Hellenic Republic concerning Directive 94/22/EC of the European Parliament and of the Council on the conditions for granting and using authorizations for the prospection, exploration and production of hydrocarbons (2014/C 400/03). http://www.ypeka.gr/LinkClick.aspx?fileticket=9\%2bjlu0190Qw\%3d\&tabid=875\&language=en-US

Zelilidis, A., Piper, D., Vakalas, I., Avramidis, P., Getsos, K., 2003. Oil and gas plays in Albania: do equivalent plays exist in Greece? Journal of Petroleum Geology, 26: 29-48. 